\section{Seroprevalence of Flavivirus in horses in Chaco, Argentina. Circulation during 2013-2014}

\author{
Soroprevalência de Flavivirus em equinos no Chaco, Argentina \\ Circulação durante 2013-2014
}

Griselda Inés Oria ${ }^{1,2}$, Lorena Ivana Spinsanti ${ }^{3}$ Verónica Laura Pirota ${ }^{4}$, Florencia Martinez ${ }^{5}$, Ornela Sofía Stechina ${ }^{6}$, Eduardo Etchepare ${ }^{7,8}$, Marta Silvia Contigiani ${ }^{9}$ \& Marina Stein ${ }^{10,11}$

1.2Lic. in Zoology, Lic. Área Entomología, Instituto de Medicina Regional - IMR, Resistencia, Chaco, Argentina, and Facultad de Medicina, Universidad Nacional del Nordeste - UNNE, Corrientes, Argentina.

${ }^{3}$ Biology, Dra. Laboratorio de Arbovirus y Arenavirus, Instituto de Virología Dr. J. M. Vanella, Facultad de Ciencias Médicas FCM, Universidad Nacional de Córdoba - UNC, Córdoba, Argentina.

${ }^{4}$ Veterinary, Médico veterinário. Dirección de Fauna, Ministerio de la Producción, Resistencia, Chaco, Argentina.

${ }^{5}$ Biochemistry, Virology Specialist. Laboratorio de Arbovirus y Arenavirus, Instituto de Virología Dr. J. M. Vanella, Universidad Nacional de Córdoba - UNC, Córdoba, Argentina.

${ }^{6}$ Biology, Lic. Área Entomología, Instituto de Medicina Regional - IMR, Universidad Nacional del Nordeste - UNNE, Resistencia, Chaco, Argentina, Consejo Nacional de Investigaciones Científicas y Técnicas - CONICET, CCT Nordeste, Corrientes, Argentina. 7.8Biology, Dr. Laboratorio de Herpetología, Facultad de Ciencias Exactas y Naturales y Agrimensura - FACENA, Universidad Nacional del Nordeste - UNNE. Consejo Nacional de Investigaciones Científicas y Técnicas - CONICET, CCT Nordeste, Corrientes, Argentina.

${ }^{9}$ Biochemistry, Dra. Laboratorio de Arbovirus y Arenavirus, Instituto de Virología Dr. J. M. Vanella, FCM, UNC, Córdoba, Argentina. 10,1Biology, Dra. Área Entomología, Instituto de Medicina Regional - IMR, Universidad Nacional del Nordeste UNNE, Resistencia, Chaco, Argentina. Consejo Nacional de Investigaciones Científicas y Técnicas - CONICET, CCT Nordeste, Corrientes, Argentina.

\begin{abstract}
Flaviviruses are responsible for several emerging mosquito-borne diseases in Argentina and in the Americas. Some of these diseases are zoonoses and were detected in recent years: West Nile virus (WNV) and Saint Louis encephalitis virus (SLEV) among them. WNV originated in Africa was detected for the first time in America in 1999 and it was first isolated from diseased and dead horses in 2006 in Argentina. Neutralizing antibodies from wild birds, humans and horses have been also detected in later years. SLEV re-emerged as a human pathogen in Argentina with the first epidemic in 2005. During this outbreak viral strains were isolated from Culex mosquitoes and several studies have detected neutralizing antibodies from birds, human and horses, in the last ten years. The aim of this work is to provide information on the activity of the Flavivirus SLEV and WNV, identifying the infection in horses in three localities of the province of Chaco. From May 2013 to May 2014, serological surveys from 68 asymptomatic horses were conducted. Antibodies against SLEV (25\%) and WNV (8.82\%) were detected. This is the first report of WNV circulation in equines from Chaco province and circulation of both viruses during the study period was demonstrated.
\end{abstract}

Keywords: Flavivirus, horses, Argentina-subtropical area.

\section{Resumo}

Os Flavivirus são responsáveis das várias doenças emergentes transmitidas pelos mosquitos na Argentina e nas Américas. Algumas dessas doenças são zoonoses e foram detectadas nos últimos anos como o vírus do West Nile (VWN) e vírus da encefalite de St. Louis (VESL). O VWN originado em África foi detectado pela primeira vez na América em 1999 e foi isolado pela primeira vez de cavalos doentes e mortos em 2006 na Argentina. Do mesmo modo, foram detectados anticorpos neutralizantes de aves selvagens, humanos e cavalos nos últimos anos. O virus St. Louis ressurgiu como um agente patogénico humano na Argentina com o primeiro surto epidemiológico em 2005. Cepas virais de mosquitos Culex foram isoladas durante esta epidemia e vários estudos detectaram anticorpos neutralizantes para aves, humanos e cavalos nos últimos dez anos. O objetivo deste trabalho é fornecer informações sobre a atividade do Flavivirus SLE e WN, identificando a infecção em cavalos em três localidades da província de Chaco, Argentina. Desde maio de 2013 até maio de 2014, foram realizadas pesquisas sorológicas em 68 cavalos assintomáticos. Foram detectados anticorpos contra VESL (25\%) e VWN (8,82\%). Este é o primeiro registro de circulação do VNO em cavalos da província de Chaco e demonstrou a circulação de ambos os vírus durante o período de estudo.

Palavras-chave: Flavivírus, cavalos, área Argentina-Subtropical.
How to cite: Oria, G.I., Spinsanti, L.I., Pirota, V. L., Martínez, M. F, Stechina, O. S. Etchepare, E., Contigiani, M. S. and Stein, M. (2018). Seroprevalence of Flavivirus in horses in Chaco, Argentina. Circulation during 2013-2014. Brazilian Journal of Veterinary Medicine, 40 , e45118. DOl: 10.29374/2527-2179.bjvm045118

Conflict of interests: No conflict of interests declared concerning the publication of this article.

Received: December 05, 2017.

Accepted: June 27, 2018.

The study was carried out at Universidad Nacional del Nordeste (UNNE), Instituto de Medicina Regional, Area Entomología, Argentina and Instituto de Virología "Dr. J.M. Vanella", Universidad Nacional de Córdoba, Argentina.

\section{*Correspondence}

Griselda Inés Oria

Área de Entomología, Instituto de Medicina Regional, Universidad Nacional del Nordeste - UNNE

Avda. Las Heras 727 (3500)

Resistencia, Chaco, Argentina

Email: grisior@gmail.com

Copyright Oria et al. This is an Open Access article distributed under the terms of the Creative Commons Attribution Non-Commercial License which permits unrestricted non-commercial use, distribution, and reproduction in any medium provided the original work is properly cited. 


\section{Introduction}

Humans, horses and other vertebrates are considered the final hosts of different arboviruses transmitted by mosquitoes. Among them, Saint Louis Encephalitis virus (SLEV) and West Nile virus (WNV) both belonging to the Japanese encephalitis antigenic complex, genus Flavivirus (Flaviviridae) (King et al., 2012), caused epidemics and/or epizootics in Argentina and in the Americas. SLEV and WNV are mosquito-borne viral infections transmitted in natural cycles between birds and mosquitoes, particularly Culex spp.(Morales et al., 2017).

WNV originated in Africa, and was detected for the first time in America in 1999, causing human epidemics and massive bird and equine death toll in the USA (Petersen \& Roehrig, 2001). Since the introduction of this virus, encephalitis outbreaks in humans, birds and equines have been detected from Canada to South America (Nash et al., 2001; Komar et al., 2003).

In Argentina, it was first isolated from diseased and dead horses in the province of Buenos Aires in 2006 (Morales et al., 2006); however, seroprevalence studies in birds from different provinces, including Chaco, confirmed its activity since 2004 (Díaz et al., 2008). Sporadic human cases have been reported in provinces of the northeast and central areas of the country (Chaco, Entre Ríos, Formosa, Santa Fe, and Córdoba provinces) but the impact on animal and human public health was considerably lower than in the northern hemisphere (Morales et al., 2017).

SLEV was first isolated in Missouri (United States of America) in 1933 and currently is widely distributed across the continent (Lumsden \& Jellison, 1958). In Argentina, the distribution of SLEV is very broad; serological evidence (in some cases, up to 50\%) for transmission has been found practically wherever it has been sought. The virus is endemic in subtropical provinces and in a number of temperate ones (Spinsanti et al., 2000). Also, in Cordoba province (temperate province in central Argentina), a human encephalitis outbreak caused by SLEV was reported in 2005 (Spinsanti et al., 2008).

Although the circulation of this viral infection has been reported in Argentina, the impact on horses health is unknown.

These Flavivirus have been largely ignored or neglected, because they have not a strong impact on the people who live in endemic areas. Due to the veterinary and medical importance of these infections, the aim of this work was to provide information on the activity of SLEV and WNV in three localities of the province of Chaco, through detection of antibodies in horses, based on background of previous researches in humans, birds and horses in the region (Sabattini et al., 1998; Díaz et al., 2008; Tauro et al., 2012); and provide useful information, contributing in surveillance and control programs for these diseases.

This study was part of a larger initiative to define Ecoepidemiology of arboviruses in Chaco province, conducted by the Department of Entomology of Instituto de Medicina Regional, Universidad Nacional del Nordeste.

\section{Materials and methods}

\section{Study area}

The Province of Chaco is located ( $28^{\circ}$ and $25^{\circ} 39^{\prime} 21^{\prime \prime} \mathrm{S} ; 61^{\circ} 42^{\prime} 40^{\prime \prime}$ and $62^{\circ} 20^{\prime} 30^{\prime} \mathrm{W}$ ) in the Northeastern of Argentina (Figure 1). The climate is subtropical with a dry season (May to November). In summer (December-February) the mean annual temperature is $27^{\circ} \mathrm{C}$, with an absolute maximum that can exceed $43^{\circ} \mathrm{C}$; the winter (June-August) is moderate, the mean monthly temperature from the coldest month is approximately $12^{\circ} \mathrm{C}$ with some frost ( 5 to 10 days per year). The daily thermal oscillation is significant and the differences of $10^{\circ} \mathrm{C}$ are frequent (Karlin, 2012). The mean rainfall between November and April is $1280 \mathrm{~mm}$ and between June and September is $650 \mathrm{~mm}$ (Bruniard, 1978).

\section{Studied localities}

1) Resistencia (RS) is the capital city of Chaco province ( $27^{\circ} 28^{\prime} \mathrm{S}, 58^{\circ} 59^{\prime} \mathrm{W}$ ) (Figure 1) belonging to San Fernando Department with 100\% urban population, estimated in 290,723 inhabitants (Instituto Nacional de Estadística y Censo, 2011). It is located within the flooded valley of Negro and Parana Rivers which makes it especially vulnerable to rain and river flooding. 


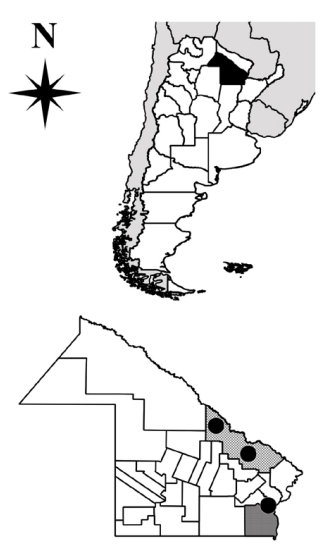

Libertador Gral San Martín Departmen San Fernando Department
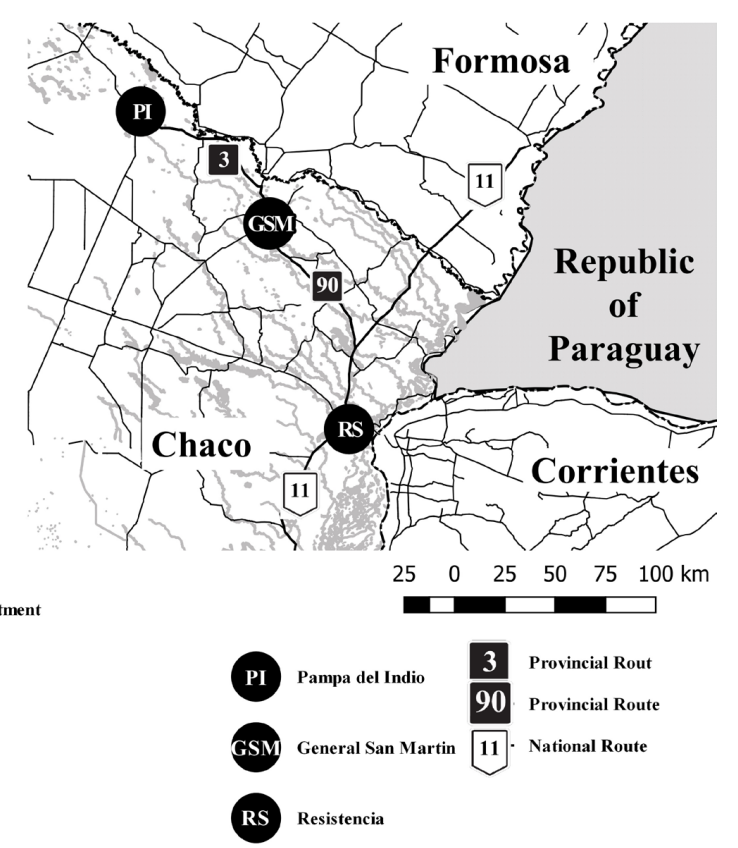

Figure 1. Map of Argentina. Chaco province and location of sampling sites.

The main economic activities are small shops and public services (21\%), public administration (13.9\%), construction (12.9\%), social and health services (6.2\%),

manufacturing industry (5.8\%) and education (5.3\%) (Instituto Nacional de Estadística y Censo, 2011).

2) General José de San Martín (GSM) city (26 32' $11^{\prime \prime}$ S, 59 $20^{\prime} 29^{\prime \prime} \mathrm{W}$ ) is distant $90 \mathrm{~km}$ from the capital city. It has 28,124 inhabitants belonging to the Libertador General San Martín Department, which is located in the central-eastern region of the province (Figure 1). It is an important region where the people participate in agricultural activities and livestock (Instituto Nacional de Estadística y Censo, 2011). This city is crossed by several provincial routes that connect it with other localities, being the place of passage of transport activities of different commercial products. The people had access to piped water.

3) Pampa del Indio (PI) city $\left(26^{\circ} 2^{\prime} \mathrm{W}^{\prime \prime} \mathrm{S}, 59^{\circ} 55^{\prime} \mathrm{W}\right)$ is distant $235 \mathrm{~km}$ from the capital city of the Chaco province. This city is located to the northeastern of the province and it has a population of 9,204 inhabitants (Instituto Nacional de Estadística y Censo, 2011) between creoles and aborigines of the Qom ethnic group. It is the second most populated city of the Libertador General San Martín Department and the 5th most populated city of the province but it has the lower urban population compared with the provincial population mean. In the urban area, the main commercial and political activities are developed. In the rural area, different economic activities are developed such as: livestock, agriculture, sawmills brickworks and coal production. The aborigine population also carries out traditional ceramics, sculpture, basketry, textiles as second source of money income. The rural population is distributed in 25 spots around the urban area of PI. Provincial Route $N^{\circ} 3$ connects this locality with GSM city (Figure 1). In the urban area, most of the people have access to piped water, but those living in the rural area collect rainwater for daily use (Chaco, 2010).

\section{Samples studied and analyzed}

The blood samples from 68 asymptomatic horses belonging to three locations of Chaco province were taken sequentially. They were collected from the jugular vein and sent to the laboratory, refrigerated and kept at $4^{\circ} \mathrm{C}$ until processing. None had a history of previous vaccination. Samples were obtained in May, September and December 2013 and May 2014. Twenty one male horses, with an age range of 6-28 years belonging to the police of the Chaco province were studied in 
RS; from GSM, 27 horses (including only 6 females) with an age range of 2-27 years were studied and finally, in PI 20 horses aged between 5 and 22 were studied.

\section{Plaque reduction neutralization test (PRNT)}

Neutralizing antibodies (NTAb) detection was performed using a PRNT with Vero cells (African green monkey kidney cells) (Earley et al., 1967). The samples were initially tested in a $1 / 10$ dilution and those that neutralized at least $80 \%$ of the inoculated viral plaques forming units were considered positive. SLEV strain CbaAr4005 isolated from Cx. quinquefasciatus mosquitoes from Córdoba (Diaz, 2006) and WNV E/7229/06 isolated from sick equines in Buenos Aires were used (Morales et al., 2006). Viral suspensions were prepared using the brains of infected lactating mice and 10\% (weight/volume) minimal essential medium with Earle salts supplemented with L-glutamine, non-essential amino acids, $10 \%$ fetal bovine serum and $1 \%$ antibiotics. The suspensions were centrifuged at 10,000 rpm for 30 min using a refrigerated centrifuge.

\section{Statistics analysis}

The age classes of the equines were adapted from (Cardona \& Álvarez, 2010; Toit, 2006). There are three classes: young ( $<5$ years), adults (6-15 years) and older ( $>16$ years).

Variance analysis (ANOVA) was used to assess the degree of statistical difference, in the presence of antibodies by age classes.

The project that gave rise to this manuscript was approved by the ethics committee (protocol 2012) of the Institute of Regional Medicine (UNNE), 2012.

\section{Results}

Seropositive animals were identified in the three surveyed locations of the Chaco province. Table 1 shows the results of the serology. Most (97.5\%) of the horses studied were seropositive for SLEV, WNV or both. Seventeen (25\%) of the horses presented monotypic reactions to SLEV, and 6 (8.82\%) presented monotypic reactions to WNV.

The highest prevalence for SLEV (38.09\%), and WNV (14.28\%) of all samples analyzed, considering only monotypic infections was detected in RS.

In PI was observed the greatest frequency of secondary infections (85\%) (Table 1).

Table 2 shows all positive samples and the horses that demonstrate recent virus circulation. A total of 25 seronegative horses in May 2013 became seropositive in later periods. Fifty two percent of recent infections were caused by SLEV, 36\% due to WNV and 12\% of horses were infected with both viruses.

The period of greatest transmission was between June 2013 and September 2013 (N=13) and occurred mainly in GSM (Table 2).

For the three localities studied no significant differences between age classes and the prevalence of Flavivirus were found ( $\mathrm{F}=0.52 ; \mathrm{p}>0.59$ ).

Table 1. Prevalence of neutralizing antibodies against SLEV and WNV, in blood samples horses, from Chaco province, Argentina, collected between May 2013 and May 2014.

\begin{tabular}{cccc}
\hline \multirow{2}{*}{ Locality } & \multicolumn{3}{c}{$\mathbf{N}^{\circ}$ positiv/tested (\%) } \\
\cline { 2 - 4 } & \multicolumn{1}{c}{ SLEV } & \multicolumn{1}{c}{ WNV } & SLEV+WNV \\
\hline RS & $8 / 21(38.09)$ & $3 / 21(14.28)$ & $8 / 21(38.09)$ \\
GSM & $7 / 27(25.90)$ & $2 / 27(7.40)$ & $18 / 27(66.66)$ \\
PI & $2 / 20(10)$ & $1 / 20(5)$ & $17 / 20(85)$ \\
Total & $17 / 68(25)$ & $6 / 68(8.82)$ & $43 / 68(63.23)$ \\
\hline
\end{tabular}


Table 2. Positive samples for antibody detection against SLEV and WNV collected between May 2013 and May 2014, from horses in Chaco province. Samples with gray shading showed recent virus circulation.

\begin{tabular}{|c|c|c|c|c|c|c|c|c|c|c|}
\hline \multirow{3}{*}{ Sample } & \multirow{3}{*}{ Locality } & \multirow{3}{*}{$\begin{array}{c}\text { Age } \\
\text { (years) }\end{array}$} & \multicolumn{8}{|c|}{ Study period } \\
\hline & & & \multicolumn{2}{|c|}{ May 2013} & \multicolumn{2}{|c|}{ September 2013} & \multicolumn{2}{|c|}{ December 2013} & \multicolumn{2}{|c|}{ May 2014} \\
\hline & & & SLEV & WNV & SLEV & WNV & SLEV & WNV & SLEV & WNV \\
\hline 48 & RS & 9 & - & + & - & & - & & - & \\
\hline 50 & RS & 15 & + & + & & & & & & \\
\hline 51 & RS & 22 & - & + & - & & - & & - & \\
\hline 52 & RS & 16 & + & - & & - & & - & & + \\
\hline 53 & RS & 18 & + & - & & - & & + & & \\
\hline 54 & RS & 18 & - & - & - & - & - & - & + & - \\
\hline 55 & RS & 25 & - & - & + & - & & - & & - \\
\hline 56 & RS & 25 & + & - & & - & & - & & - \\
\hline 58 & RS & 20 & - & + & - & & - & & + & \\
\hline 59 & RS & 20 & - & - & - & - & + & - & & - \\
\hline 60 & RS & 6 & - & + & - & & + & & & \\
\hline 61 & RS & 25 & - & + & - & & - & & + & \\
\hline 62 & RS & 28 & - & + & - & & - & & - & \\
\hline 63 & RS & 25 & + & - & & - & & - & & - \\
\hline 64 & RS & 16 & + & + & & & & & & \\
\hline 65 & RS & 24 & + & - & & - & & - & & - \\
\hline 66 & RS & 18 & - & - & - & - & + & - & & - \\
\hline 67 & RS & 25 & + & - & & + & & & & \\
\hline 68 & RS & 15 & - & - & + & - & & - & & - \\
\hline 21 & GSM & 8 & + & + & & & & & & \\
\hline 22 & GSM & 10 & + & - & & + & & & & \\
\hline 23 & GSM & 15 & + & - & & - & & - & & - \\
\hline 24 & GSM & 8 & - & - & + & + & & & & \\
\hline 25 & GSM & 12 & + & - & & - & & + & & \\
\hline 26 & GSM & 12 & + & - & & - & & - & & - \\
\hline 27 & GSM & 6 & + & + & & & & & & \\
\hline 28 & GSM & 25 & - & + & + & & & & & \\
\hline 29 & GSM & 24 & - & - & - & - & - & - & + & - \\
\hline 30 & GSM & 25 & + & + & & & & & & \\
\hline 31 & GSM & 25 & + & + & & & & & & \\
\hline 32 & GSM & 25 & - & + & + & & & & & \\
\hline 33 & GSM & 27 & + & + & & & & & & \\
\hline 34 & GSM & 25 & + & + & & & & & & \\
\hline 35 & GSM & 6 & + & - & & + & & & & \\
\hline 36 & GSM & 25 & + & - & & - & & - & & - \\
\hline 37 & GSM & 6 & + & + & & & & & & \\
\hline 38 & GSM & 4 & + & + & & & & & & \\
\hline 39 & GSM & 3 & - & + & - & & - & & - & \\
\hline
\end{tabular}


Table 2. Continued...

\begin{tabular}{|c|c|c|c|c|c|c|c|c|c|c|}
\hline \multirow{3}{*}{ Sample } & \multirow{3}{*}{ Locality } & \multirow{3}{*}{$\begin{array}{c}\text { Age } \\
\text { (years) }\end{array}$} & \multicolumn{8}{|c|}{ Study period } \\
\hline & & & \multicolumn{2}{|c|}{ May 2013} & \multicolumn{2}{|c|}{ September 2013} & \multicolumn{2}{|c|}{ December 2013} & \multicolumn{2}{|c|}{ May 2014} \\
\hline & & & SLEV & WNV & SLEV & WNV & SLEV & WNV & SLEV & WNV \\
\hline 40 & GSM & 2 & + & - & & - & & - & & - \\
\hline 41 & GSM & 2 & + & - & & - & & - & & - \\
\hline 42 & GSM & 4 & + & + & & & & & & \\
\hline 43 & GSM & 6 & - & + & - & & - & & - & \\
\hline 44 & GSM & 6 & + & - & & - & & - & & - \\
\hline 45 & GSM & 6 & + & - & & + & & & & \\
\hline 46 & GSM & 3 & + & + & & & & & & \\
\hline 47 & GSM & 5 & + & - & & - & & + & & \\
\hline 1 & PI & 9 & + & + & & & & & & \\
\hline 2 & PI & 18 & + & + & & & & & & \\
\hline 3 & PI & 19 & + & + & & & & & & \\
\hline 4 & PI & 5 & + & + & & & & & & \\
\hline 5 & PI & 17 & - & - & - & + & - & & - & \\
\hline 6 & PI & 15 & + & - & & - & & - & & - \\
\hline 7 & PI & 5 & + & + & & & & & & \\
\hline 8 & PI & 7 & - & - & - & - & + & - & & + \\
\hline 9 & PI & 22 & + & + & & & & & & \\
\hline 10 & PI & 20 & + & + & & & & & & \\
\hline 11 & PI & 10 & + & + & & & & & & \\
\hline 12 & PI & 22 & + & + & & & & & & \\
\hline 13 & PI & 18 & + & + & & & & & & \\
\hline 14 & PI & 17 & + & + & & & & & & \\
\hline 15 & PI & 10 & + & + & & & & & & \\
\hline 16 & PI & 10 & + & - & & + & & & & \\
\hline 17 & PI & 7 & - & - & + & + & & & & \\
\hline 18 & PI & 7 & + & + & & & & & & \\
\hline 19 & PI & 10 & - & + & + & & & & & \\
\hline 20 & PI & 15 & + & - & & - & & - & & - \\
\hline
\end{tabular}

\section{Discussion}

Several arboviruses have been emerged and reemerged in the New World in the past decades. WNV was reported in North America since 1999 and it rapidly extended causing human and equine encephalitis outbreaks every year and the decline of some wild bird populations (Roehrig, 2013). Today it is active in most countries of the Americas. The biological transmission cycle of WNV is maintained by Culex spp. mosquitoes, which act as vectors and Passeriformes birds as vertebrate hosts (Komar et al., 2003). Díaz et al. (2008) found antibodies against WNV in birds from three provinces in Argentina including the province of Chaco, and suggested that the species of the Furnariidae family are competent hosts of the virus and could play an important role in the transmission of this virus in Argentina. Although, to date, the species of birds and mosquitoes involved in the transmission cycle of WNV in Argentina are still unknown.

This is the first report of seroprevalence of WNV in equines, in Chaco province. 
Morales et al. (2017) found 8.33\% antibody prevalence for WNV in black howlers from Chaco and Corrientes provinces (Subtropical region) similar to our findings. Nevertheless Tauro et al. (2012) detected the highest seroprevalence for WNV (16.2\%) in horse samples collected in the central and south of Santa Fe province (Temperate region) (Biasatti, 2016), which is different from subtropical climate of the present study, particularly regarding the temperature and rainfall (winter mean temperature: $9^{\circ} \mathrm{C}$; mean precipitation during rainy season: $900 \mathrm{~mm}$ ), indicating possible environmental influences on the eco-epidemiology of this virus.

In Argentina SLEV was isolated from rodents Calomys sp. of the province of Córdoba in 1966 and from mosquitoes Cx. quinquefasciatus in Santa Fé (Monath et al.,1985) and Córdoba province during the first epidemic of SLEV human encephalitis in 2005 (Diaz et al., 2006). Culex quinquefasciatus and $C x$. interfor mosquitoes act as primary vectors and Zenaida auriculata (Eared doves) and Columbina picui (picui ground doves) act as urban vertebrate hosts (Díaz, 2009; Batallan et al., 2010). In the different localities studied from Chaco both species of birds and the mosquitoes vector species mentioned above are abundant, however, to date no result has been obtained on detection or isolation of SLEV from these hosts (Oria et al., in press).

Likewise, Monath et al. (1985) detected infection in equines from four Argentinean provinces (some subtropical and some temperate), including Chaco province, showing a prevalence greater than $50 \%$ for SLEV. They found a significantly higher prevalence in subtropical provinces. In the same study, these authors performed the first work in Argentina with sentinel horses from Santa Fé province showing the active circulation of SLEV in the 80's. In the present study, seroprevalence for SLEV was lower than those founded by Monath et al.(1985). Our values may be underestimated because only were considered positive those that showed monotypic responses. However, considering the total number of SLEV infections plus infections from both viruses (SLE and WN) the prevalence of SLEV remains similar as that found more than 30 years ago.

Avilés \& Sabattini (1998) detected 68\% of seroprevalence in humans for SLEV in Chaco (Sauzalito) and Spinsanti et al. (2000) detected prevalence of AcNT against SLEV in Formosa province, bordering north with the province of Chaco.

Likewise, Spinsanti et al. (2002) found 13.3\% of AcNT against SLEV, from serological screening performed to individuals living in Córdoba city between 1998 and 2000. In the same study, these authors demonstrated significant statistical relationship between the presence of neutralizing antibodies and the age of the subjects. In the present study, it was not possible to demonstrate any association between the age classes of the equines and the virus infections.

SLEV is endemic in the north and central regions of Argentina and since 2004 coexists with WNV. Different studies have revealed the co-circulation of both viruses (Oria et al., 2012; (Spinsanti et al., 2012; Tardei et al., 2000; Diaz et al., 2016; Morales et al., 2017) as the present study.

Tauro et al. (2012) detected in horses from Santa Fé province a seroprevalence of 48.6\% for both viruses. Morales et al. (2017) detected a high heterotypic response for WNV and SLEV (25\%) in black howlers in localities near the present study area. In our study, this scenario was more evident in GSM and PI where the prevalence of heterotypic response was the highest.

SLEV was recognized in several human encephalitis outbreaks in Argentina in the last decade (Fabbri et al., 2008), therefore, the co-circulation with WNV must be kept in mind because could complicate the interpretation of serological test (Morales et al., 2017).

While the antigenic similarities between different flaviviruses lead to wide cross-reactivity, there are studies that have evaluated cross reaction among SLEV and WNV in heterologous inoculation scenarios indicated low or not cross reaction (Ledermann et al., 2011; Diaz et al., 2016)

Therefore, we could think that the infections of some equines by both viruses found in the present study would correspond to sequential or secondary infections.

The detection of these viruses in the present study in localities not previously cited as RS and GSM, allowed to update the range of distribution of these viruses in the study region.

Our study has also allowed demonstrating recent infection for the two viruses studied, from sequential samples of serum taken at different times of the year, indicating active circulation in the study area during that period. According to our data, September was the month that presented the highest number of recent infection, possibly indicating May-September 2013, as the period in which the transmission of these viruses mainly occurs. However, the detection of antibody in all study period suggests that the transmission also occurred between spring 2013 and autumn 2014. 
These results suggest the need for additional studies on viral circulation in mosquitoes and hosts.

Although equines are important WNV vertebrate hosts, only a limited number of dead or diseased horses have been diagnosed in America (Díaz et al., 2013). These authors suggest that prior exposure to others Flavivirus could modulate the disease in subsequent exposures to WNV, which could be a possible explanation that none of the horses infected with this virus in the present study have developed a clinical response.

The behavior of this virus differs from that observed in the USA, mainly due to the absence of epizootics in horses and wild birds and epidemics in human populations, similar to that happens in other South American countries. The causes of these differences are unknown.

\section{Conclusion}

In conclusion, the detection of antibodies against the two viruses studied, especially revealed in the second and / or third samples in horses in three localities of the present research, show active transmission of them in the province. The high prevalence of positive equines in the three studied localities allows us to suggest that the province of Chaco it is also favorable place for the presence of vectors and hosts for these viral agents with wide distribution of them in the study area.

SLEV is known to cause subclinical infections in horses nevertheless; the first isolation of SLEV from a horse that died due to a neurological disease in Brazil is a significant event. This is the first observation that SLEV can cause disease in horses, which indicates that some aspects of its viral cycle and its ability to cause disease need further studies (Díaz et al., 2013).

This should be considered with attention by the health authorities not only because the possibility of epidemic outbreaks but also because it complicates diagnosis in persons repeatedly exposed to multiple flaviviruses in the study area, including dengue viruses. On the other hand, it is also necessary to deepen the studies on these infectious agents, mosquito vectors and vertebrate hosts involved in the cycles of transmission in the province of Chaco.

\section{Acknowledgement}

- We thank to the Director of Health and Agro-Food Quality Service of the Province of Chaco, owners of equines in rural establishments for authorizing the taking of blood samples and their transport for the study.

- Rural workers for collaboration in taking blood samples.

- Responsible for the Provincial Direction of Rural Police of Resistance: authorization and logistical support for taking blood sampling of their horses.

- Ms. Mariana Climent for the revision of the manuscript in English version.

\section{References}

Avilés, G., \& Sabattini, M. (1998). Encefalitis de San Luis: genotipos, ciclos y enfermedad - temas de zoonosis y enfermedades emergentes. In II Congreso Argentino de Zoonosis y I Congreso Argentino y Latinoamericano de Enfermedades Emergentes. Buenos Aires: Aazoonosis.

Batallan, G., Pisano, M. B., Tauro, L., Grech, M., Sartor, P., Berrón, C., Almirón, W., Ré, V., \& Contigini, M. (2010). Circulación del VESL en mosquitos en la ciudad de Córdoba en la temporada verano 2010. In XXX Reunión Científica Anual de la Sociedad Argentina de Virología. Córdoba, Argentina: AAM.

Biasatti, N. R. (2016) Las ecoregiones, su conservación y las áreas naturales protegidas de la provincia de Santa Fe. Santa Fe: Ministerio de Medio Ambiente.

Bruniard, E. D. (1978). El gran Chaco argentino: ensayo de interpretación geográfica. Revista Geografica Digital, 4, 259.

Cardona, J. A., \& Álvarez, J. (2010). Estimación de la edad de los caballos basado en el examen dentario. Revista Udca Actualidad \& Divulgacion Cientifica, 13(1), 29-39.

Chaco. (2010). Informe técnico de la dirección provincial de estadística y censo. San Luis: INDEC.

Díaz L.A., Flores F.S., Quaglia A. \& Contigiani M.S. (2013). Intertwined arbovirus transmission activity: reassessing the transmission cycle paradigm. Frontiers in Physiology, 3, 493. http://dx.doi.org/10.3389/fphys.2012.00493.

Díaz, L. A. 2009. Patrones de actividad y estacionalidad del virus St. Louis encephalitis en Córdoba (PhD tesis). Universidad Nacional de Cordoba, Argentina.

Díaz, L. A., Occelli, M., Almeida, F. L., Almirón, W. R., \& Contigiani, M. S. (2008). Eared dove (Zenaida auriculata, Columbidae) as host for St. Louis encephalitis virus (Flaviviridae, Flavivirus). Vector Borne and Zoonotic Diseases (Larchmont, N.Y.), 8(2), 277-282. http://dx.doi.org/10.1089/vbz.2007.0168. PMid:18429694. 
Diaz, L. A., Quaglia, A. I., Konigheim, B. S., Boris, A. S., Aguilar, J. J., Komar, N., \& Contigiani, M. S. (2016). Activity patterns of St. Louis encephalitis and west nile viruses in free rangira birds during a human encephalitis outbreak in Argentina. PLoS One, 11(8), e0161871. http://dx.doi.org/10.1371/journal.pone.0161871. PMid:27564679.

Diaz, L., Re, V., Almiron, W., Farias, A., Vazquez, A., Paz Sanchez-Seco, M., Aguilar, J., Spinsanti, L., Konigheim, B., Visintin, A., Garcia, J., Morales, M., Tenorio, A., \& Contigiani, M. (2006). Genotype III Saint Louis Encephalitis virus outbreak, Argentina, 2005. Emerging Infectious Diseases, 12(11), 1752-1754. http://dx.doi.org/10.3201/ eid1211.060486. PMid:17283629.

Earley, E., Peralta, P. H., \& Johnson, K. M. (1967). A plaque neutralization method for arboviruses. Proceedings of the Society for Experimental Biology and Medicine, 125(3), 741-747. http://dx.doi.org/10.3181/00379727-12532194. PMid:15938255.

Fabbri C, García J, Morales MA, Levis S, Enría D. y Lanciotti R. (2008). Secuenciación genómica completa y análisis filogenético de dos cepas de virus WN aisladas en Argentina. Revista Argentinade Microbiología 40 (Supl. 1):56

Instituto Nacional de Estadística y Censo - INDEC. (2011). Censos nacionales de población, hogares y vivienda 2001 y 2010. San Luis: Dirección Provincial de Estadística y Censo de la Provincia del Chaco. Retrieved in 2016, May 16, from http://www.estadistica.sanluis.gov.ar/estadisticaWeb/Contenido/Pagina148/File/LIBRO/ censo2010_tomo1.pdf

Karlin, M. S. (2012). Temporal changes of the climate in Arid Chaco subregión. Multequina Latin American Journal of Natural Resources, 21(1), 3-16. Retrieved in 2016, March 11, from http://www.scielo.org.ar/scielo. php?script=sci_arttext\&pid=S1852-73292012000100001\&lng=es\&tlng=es

King, A. M. Q., Adams, M. J., Carstens, E. B., \& Lefkowitz, E. J. (2012). Virus taxonomy: ninth report of the international committee on taxonomy of viruses. San Diego: Elsevier Academic Press.

Komar, N., Langevin, S., Hinten, S., Nemeth, N., Edwards, E., Hettler, D., Davis, B., Bowen, R., \& Bunning, M. (2003). Experimental Infection of North American Birds with the New York 1999 Strain of West Nile Virus. Emerging Infectious Diseases, 9(3), 311-322. http://dx.doi.org/10.3201/eid0903.020628. PMid:12643825.

Ledermann, J. P., Lorono-Pino, M. A., Ellis, C., Saxton-Shaw, K. D., Blitvich, B. J., Beaty, B. J., Bowen, R. A., \& Powers, A. M. (2011). Evaluation of widely used diagnostic tests to detect west nile virus infections in horses previously infected with St. Louis Encephalitis Virus or Dengue Virus Type 2. Clinical and Vaccine Immunology; CVI, 18(4), 580-587. http://dx.doi.org/10.1128/CVI.00201-10. PMid:21346058.

Lumsden, L. L. ST., \& Jellison, W. L. (1958). Louis encephalitis in 1933: observations on epidemiological features. Public Health Reports, 73(4), 340-353. http://dx.doi.org/10.2307/4590109. PMid:13542726.

Monath, T. P., Sabattini, M. S., Pauli, R., Daffner, J. F., Mitchell, C. J., Bowen, G. S., \& Cropp, C. B. (1985). Arbovirus investigations in Argentina, 1977-1980. IV. Serological surveys and sentinel equine program. The American Journal of Tropical Medicine and Hygiene, 34(5), 966-975. http://dx.doi.org/10.4269/ajtmh.1985.34.966. PMid:2863991.

Morales, M. A., Barrandeguy, M., Fabbri, C., Garcia, J. B., Vissani, A., Trono, K., Gutierrez, G., Pigretti, S., Menchaca, H., Garrido, N., Taylor, N., Fernandez, F., Levis, S., \& Enría, D. (2006). West Nile virus isolation from equines in Argentina, 2006. Emerging infectious diseases, 12(10), 1559-1561. http://dx.doi.org/10.3201/eid1210.060852. PMid:17176571.

Morales, M. A., Fabbri, C. M., Zunino, G. E., Kowalewski, M. M., Luppo, V. C., Enría, D. A., Levis, S. C., \& Calderón, G. E. (2017). Detection of the mosquito-borne flaviviruses, West Nile, Dengue, Saint Louis Encephalitis, Ilheus, Bussuquara, and Yellow Fever in free-ranging black howlers (Alouatta caraya) of Northeastern Argentina. PLoS Neglected Tropical Diseases, 11(2), e0005351. http://dx.doi.org/10.1371/journal.pntd.0005351. PMid:28187130.

Nash, D., Mostashari, F., Fine, A., Miller, J., O'Leary, D., Murray, K., Huang, A., Rosenberg, A., Greenberg, A., Sherman, M., Wong, S., Campbell, G. L., Roehrig, J. T., Gubler, D. J., Shieh, W.-J., Zaki, S., Smith, P., \& Layton, M. (2001). The outbreak of West Nile virus infection in the New York City area in 1999. The New England Journal of Medicine, 344(24), 1807-1814. http://dx.doi.org/10.1056/NEJM200106143442401. PMid:11407341.

Oria, G. I., Spinsanti, L., Huenten, D., Pisano, B., Beranek, M., Aguirre, L., \& Contigiani, M. S. (2012). Estudio de seroprevalencia de Flavivirus y Alfavirusen humanos de la Provincia de Chaco, Argentina. In XII Congreso de la Sociedad Argentina de Infectología (in press). Cordoba, Argentina: SADI.

Petersen, L. R., \& Roehrig, J. T. (2001). West Nile virus: a reemerging global pathogen. Emerging Infectious Diseases, 7(4), 611-614. http://dx.doi.org/10.3201/eid0704.017401. PMid:11585520.

Roehrig, J. T. (2013). West nile virus in the United States - a historical perspective. Viruses, 5(12), 3088-3108. http:// dx.doi.org/10.3390/v5123088. PMid:24335779.

Sabattini, M. S., Avilés, G., \& Monath, T. P. (1998). Historical, epidemiological and ecological aspects of arbovirus in Argentina: Flaviviridae, Bunyaviridae and Rhabdoviridae. In A. P. A. T. Rosa, P. F. C. Vasconcelos \& J. F. S. T. Rosa (Eds.), An overview of arbovirology in Brazil and neighboring countries (pp. 113-134). Belém: Instituto Evandro Chagas.

Spinsanti, L. I., Díaz, L. A., Glatstein, N., Arselán, S., Morales, M. A., Farías, A. A., Fabbri, C., Aguilar, J. J., Ré, V., Frías, M., Almirón, W. R., Hunsperger, E., Siirin, M., Da Rosa, A. T., Tesh, R. B., Enría, D., \& Contigiani, M. (2008). Human outbreak of St. Louis encephalitis detected in Argentina, 2005. Journal of Clinical Virology, 42(1), 27-33. http://dx.doi.org/10.1016/j.jcv.2007.11.022. PMid:18249032. 
Spinsanti, L. I., Ré, V. E., Díaz, M. P., \& Contigiani, M. S. (2002). Age-related seroprevalence study for St. Louis encephalitis in a population from Cordoba, Argentina. Revista do Instituto de Medicina Tropical de Sao Paulo, 44(2), 59-62. http://dx.doi.org/10.1590/S0036-46652002000200001. PMid:12048540.

Spinsanti, L. I., Re, V., Basualdo, M. A., Díaz, G., Yacci, M. R., \& Contigiani, M. (2000). Seroprevalencia de infección por el virus encefalitis San Luis en la provincia de Formosa. Medicina, 60(4), 474-476. PMid:11188954.

Spinsanti, L., Vergara Cid, C., \& Contigiani, M. (2012). Relevancia en salud pública de Flavivirus neurotrópicos concurrentes endémicos y emergentes en Córdoba. Boletín de la Asociación Argentina de Microbiología, 198, 7-9.

Tardei, G., Ruta, S., Chitu, V., Rossi, C., Tsai, T. F., \& Cernescu, C. (2000). Evaluation of Immunoglobulin M (IgM) and IgG Enzyme Immunoassays in Serologic Diagnosis of West Nile Virus Infection. Journal of Clinical Microbiology, 38(6), 2232-2239. PMid:10834982.

Tauro, L., Marino, B., Díaz, L. A., Lucca, E., Gallozo, D., Spinsanti, L., \& Contigiani, M. (2012). Serological detection of St. Louis encephalitis virus and West Nile virus in equines from Santa Fe, Argentina. Memorias do Instituto Oswaldo Cruz, 107(4), 553-556. http://dx.doi.org/10.1590/50074-02762012000400019. PMid:22666870.

Toit, N. (2006). Age related changes in dentition. In IVIS - International Veterinary Information Service. Lexington: American Association of Equine Practitioners. Retrieved in 2017, February 27, from http://www.ivis.org/ proceedings/aaepfocus/2006/dutoit1.pdfArticle 